\title{
INFLUENCE OF SUBSIDIES ON TECHNICAL EQUIPMENT AND EFFICIENCY OF FAMILY FARMS
}

\author{
Zbigniew WASĄG \\ Social Insurance Institution Branch in Biłgoraj, POLAND \\ E-mail: zbigniew.wasag1@wp.pl
}

Keywords: technical equipment of holdings, amount of subsidy, economic size, holding income, sustainable agricultural production

\begin{abstract}
The aim of the study was to determine the influence of subsidies on the technical equipment of holdings. The level of technical equipment of holdings, considering the amount of subsidies, economic size and income, in the period before and after receiving subsidies, shows a growing tendency. The greatest changes were noticed in the group of holdings with subsidies within 100-150 thousand PLN (number of tractors of a power over $50 \mathrm{~kW}$ - an increase by $450 \%$ pcs $\cdot 100$ holdings $^{-1}$ ). In all the studied groups, the highest increase (by about 200\%) was noted in the number of tractors with a power over $50 \mathrm{~kW}$. An increase in in the economic size (ESU - Economic Size Unit) and in the level of generated income has a significant influence on the level of mechanization of holdings. The efficiency of support technical equipment is considerably higher in groups of holdings with the highest values of the criteria of division than in groups with lower values of the division criteria. The evaluation of the relationship between received funds and the technical modernization of the holdings under study, in the context of sustainable development, allows us to conclude that social sustainability is present in small holdings.
\end{abstract}

\section{INTRODUCTION}

Factors of production are always connected with human labour, they are referred to as the productive forces of the production process which are present in the relations between means of production (capital) and labour power (labour). That is why labour ( $\mathrm{mh}$ - manhours, or labour-hours) and the workplace (of a person) have to be assisted by technical equipment to achieve high efficiency of mechanization of agricultural production (Kocira and Sawa 2008). The technical condition and the structure of means of mechanization in given (organizational-economic) conditions of production shape the production process and define management efficiency in agriculture, which is a significant factor for farmers when they make decisions concerning investment purchases and sources to finance the said purchases. (Sawa 1994, Wójcicki and Pawlak 1996). As shown by numerous studies, the level of agricultural technical equipment of holdings, including the quantity, type, value and efficiency of machines and the power of tractors, varies greatly between individual holdings, even those with similar scope of production (Tabor 2004, Muzalewski 2007). Diversified holdings, with mixed directions of production, usually require diversified machines (Strategia... 2008). Differences in the number of tractors and agricultural machines are, first of all, the result of a disproportion between the development and the economic size of individual entities. In Biłgoraj County, the factor which influences the level of technical equipment of holdings is the particular form of mechanization of principal field work. The are no well-developed mechanization services and most farmers aim to achieve selfsufficiency with respect to agricultural equipment, and holdings make use of external services only when harvesting (Strategia... 2008). The possession of their own machine is a guarantee of its availability, which is especially important in unfavourable weather conditions. 
The introduction of another new machine to the holding should contribute, among others, to an improvement in the organization of production, productivity and promptness of field works, quality of machine work. It should also improve work conditions and safety of operators as well as decrease the unfavourable environmental influence of agricultural machinery (Muzalewski 2008, Wasąg 2008).

\section{THE AIM, SCOPE AND METHODOLOGY OF THE STUDY}

The aim of the study was to determine the influence of subsidies on the technical equipment of holdings. 70 agricultural holdings from Biłgoraj County were studied in the period before and after receiving subsidies from EU funds (purposive sampling). The period is different for individual holdings because in the years 2004-2009 they received different forms of subsidies. The period under analysis was a minimum of two years before and two years after receiving subsidies based on business plans filed by farmers with the Agency for Restructuring and Modernization of Agriculture in the years 2004-2009 (Plan... 2004; Sektorowy... 2004; Program... 2007). In order to assess the condition of agricultural technical equipment, the sample of holdings was divided on the basis of the amount of subsidies, their economic size and their income. The study contains empirical data from completed undertakings, presenting the level of ownership of major machines and equipment in the base year (before subsidies) and in the target year (after subsidies). The indicators are grouped into: level of technical equipment per holdings (pcs 100 holdings $^{-1}$ ) and technical equipment per farmland area (pcs $100 \mathrm{ha}^{-1}$ AL - Agricultural Land). The level of agricultural sustainability in the holdings under study was evaluated in the social context (Sawa et al., 2006).

\section{RESULTS OF THE STUDY}

The level of means of mechanization of holdings, considering the amount of subsidies (table 1) in the period before and after subsidies, shows a growing tendency. The highest level is present in the group with subsidies up to 50 and from 50 to 100 thousand PLN in the number of tillage machines and tools, respectively: 121.4 and 180.0 pcs 100 holdings $^{-1}$ and in total tractors: 50.0 and 72.9 pcs $\cdot 100$ holdings $^{-1}$. These groups also show a significant share of, respectively: tractor trailers 34.3 and 48.6 pcs $\cdot 100$ holdings $^{-1}$ and spraying machines 30.0 and 40.0 pcs $\cdot 100$ holdings ${ }^{-1}$. Holdings both of smaller sizes and receiving lower subsidies (up to 50 thousand PLN) in comparison with holdings with subsidies over 150 thousand PLN have better means of mechanization - tractors and tillers, respectively: 50.0 and 47.1 and 121.4 and 84.3 pcs 100 holdings $^{-1}$. The highest change in the level of means of mechanization of holdings in the target year as compared with the base year was noted in the group of holdings with the amount of subsidies from 100 to 150 thousand PLN (number of tractors of a power over $50 \mathrm{~kW}$ - an increase by $450 \%$ pcs 100 holdings $^{-1}$ ).

An evaluation of the conversion level of total tractors in holdings according to their economic size and to their income (tables 2 and 3) shows an increased level of the holdings' equipment, respectively up to 8 ESUs (16.8 pcs $\cdot 100$ holdings $\left.^{-1} \mathrm{AL}\right)$ and up to 10 thousand PLN ( 22 pcs 100 holdings $^{-1} \mathrm{AL}$ ). Whereas the percentage increase in the level of equipment in those holdings in the target year is the highest in the group from 16 to 40 ESUs (65) and over 50 thousand PLN (66). However, in the whole studied group, all groups have the highest increase (ca. 200\%) in the number of tractors with a power over $50 \mathrm{~kW}$, which can indicate the use of higher efficiency machines and tools. Whereas, holdings of smaller economic sizes (up to 8 and between 8 and 16 ESUs) 
purchased currant harvesters, which supports their aim (defined in the business plan) to increase of machine efficiency (table 2). The level of mechanization of those holdings was several times higher than the bigger ones in individual groups of technical equipment. Sawa (1998) made similar findings, which can evidence the continuing tendency towards an irrational use of equipment and towards generating maintenance and operating costs. However, this increases the comfort and quality of work and reduces the number of, for example, drives of combined cultivators in fields. Due to the specificity of the county under study, in which small holdings prevail, a situation like this is a sign of social sustainability.

A multidirectional analysis of these holdings confirms that a growth in the economic size (ESU) and in the level of generated income have a considerable influence on the level of mechanization of those holdings. An exceptional situation arises when the income of holdings is taken into consideration (table 3 ), in which case its increase is accompanied by a clear decrease, e.g. in the total number of tractors from 22.0 pcs $\cdot 100$ holdings $^{-1} \mathrm{AL}$ (with income up to 10 thousand PLN) to 4.8 pcs 100 holdings $^{-1}$ AL (with income over 50 thousand PLN).

Table 1. Changes in the equipment of farms with tractors and major agricultural machinery considering the amount of subsidies

\begin{tabular}{|c|c|c|c|c|c|c|c|c|c|c|c|c|}
\hline \multirow[b]{3}{*}{ Specification } & \multicolumn{12}{|c|}{$\begin{array}{l}\text { Agricultural equipment (pcs } 100 \text { holdings }^{-1} \text { ) in holdings with respect to the amount } \\
\text { of subsidy }\end{array}$} \\
\hline & \multicolumn{3}{|c|}{$<50$} & \multicolumn{3}{|c|}{$50-100$} & \multicolumn{3}{|c|}{$100-150$} & \multicolumn{3}{|c|}{$>150$} \\
\hline & by & ty & $\begin{array}{c}\text { change, } \\
\text { base } \\
\text { year }= \\
100 \\
\end{array}$ & by & ty & $\begin{array}{c}\text { change, } \\
\text { base } \\
\text { year }= \\
100\end{array}$ & by & ty & $\begin{array}{c}\text { change, } \\
\text { base } \\
\text { year }= \\
100\end{array}$ & by & ty & $\begin{array}{c}\text { change, } \\
\text { base } \\
\text { year }= \\
100 \\
\end{array}$ \\
\hline Total tractors, including: & 42.9 & 50.0 & 117 & 41.4 & 72.9 & 176 & 14.3 & 27.1 & 190 & 30.0 & 47.1 & 157 \\
\hline- up to $30 \mathrm{~kW}$ & 10.0 & 10.0 & 100 & 18.6 & 21.4 & 115 & 2.9 & 2.9 & 100 & 4.3 & 4.3 & 100 \\
\hline$-30-50 \mathrm{~kW}$ & 21.4 & 27.1 & 127 & 11.4 & 21.4 & 188 & 8.6 & 8.6 & 100 & 7.1 & 7.1 & 100 \\
\hline - over $50 \mathrm{~kW}$ & 11.4 & 14.3 & 125 & 11.4 & 30.0 & 263 & 2.9 & 15.7 & 550 & 18.6 & 35.7 & 192 \\
\hline Tractor trailers & 31.4 & 34.3 & 109 & 35.7 & 48.6 & 136 & 19 & 21.4 & 115 & 44 & 50 & 113 \\
\hline $\begin{array}{l}\text { Other trailers and manure } \\
\text { spreaders }\end{array}$ & 20.0 & 20.0 & 100 & 27.14 & 37.1 & 137 & 4.3 & 4.3 & 100 & 14 & 21 & 150 \\
\hline Reloading equipment & 14.3 & 18.6 & 130 & 5.7 & 21.43 & 375 & 4.3 & 10.0 & 233 & 19 & 26 & 138 \\
\hline $\begin{array}{l}\text { Machines and equipment: } \\
\text { - tillers }\end{array}$ & 98.6 & 121.4 & 123 & 140.0 & 180.0 & 129 & 53 & 77.1 & 146 & 61 & 84.3 & 137 \\
\hline - ridgers & 11.4 & 11.4 & 100 & 25.7 & 25.7 & 100 & 2.9 & 2.9 & 100 & 4.3 & 4.3 & 100 \\
\hline - fertilizer and lime distributors & 21.4 & 24.3 & 113 & 27.1 & 35.7 & 132 & 13 & 15.7 & 122 & 17 & 20.0 & 117 \\
\hline - seed drills & 24.3 & 25.7 & 106 & 28.6 & 34.3 & 120 & 11 & 15.7 & 138 & 19 & 27 & 146 \\
\hline - sprayers & 22.9 & 30.0 & 131 & 28.6 & 40.0 & 140 & 10 & 14.3 & 143 & 14 & 22.9 & 160 \\
\hline Combine harvesters & 8.6 & 8.6 & 100 & 12.9 & 12.9 & 100 & 1.4 & 1.4 & 100 & 11 & 14.3 & 125 \\
\hline Balers & 17.1 & 20.0 & 117 & 18.6 & 24.3 & 131 & 5.7 & 5.7 & 100 & 10 & 15.7 & 157 \\
\hline Root crop harvesters & 5.7 & 5.7 & 100 & 5.7 & 5.7 & 100 & 1.4 & 1.4 & 100 & 5.7 & 5.7 & 100 \\
\hline Currant harvesters & 2.9 & 4.3 & 150 & 1.4 & 2.9 & 200 & - & - & - & 1.4 & 2.9 & 200 \\
\hline Feed making machines & 4.3 & 4.3 & 100 & 7.1 & 15.7 & 220 & 1.4 & 4.3 & 300 & 15.7 & 15.7 & 100 \\
\hline
\end{tabular}

by - base year (before subsidies), ty - target year (after subsidies) 
Table 2. Equipment of farms with tractors and major agricultural machinery with respect to economic size

\begin{tabular}{|c|c|c|c|c|c|c|c|c|c|c|c|c|}
\hline \multirow[b]{3}{*}{ Specification } & \multicolumn{12}{|c|}{$\begin{array}{l}\text { Agricultural equipment (pcs } 100 \mathrm{ha}^{-1} \mathrm{AL} \text { ) in holdings with respect to economic size } \\
\text { (ESU) }\end{array}$} \\
\hline & \multicolumn{3}{|c|}{$<8$} & \multicolumn{3}{|c|}{$8-16$} & \multicolumn{3}{|c|}{$16-40$} & \multicolumn{3}{|c|}{$>40$} \\
\hline & by & ty & $\begin{array}{c}\text { change, } \\
\text { base } \\
\text { year }= \\
100\end{array}$ & by & ty & $\begin{array}{c}\text { change, } \\
\text { base } \\
\text { year }= \\
100\end{array}$ & by & ty & $\begin{array}{c}\text { chang, } \\
\text { base } \\
\text { year }= \\
100\end{array}$ & by & ty & $\begin{array}{c}\text { change, } \\
\text { base } \\
\text { year }= \\
100\end{array}$ \\
\hline Total tractors, including: & 10.7 & 16.8 & 157 & 10.8 & 15.2 & 141 & 3.4 & 5.6 & 165 & 2.9 & 4.1 & 141 \\
\hline - up to $30 \mathrm{~kW}$ & 6.8 & 7.5 & 110 & 2.7 & 3.0 & 111 & 0.8 & 0.7 & 88 & 0.4 & 0.4 & 100 \\
\hline$-30-50 \mathrm{~kW}$ & 1.7 & 5.2 & 306 & 6. & 7.2 & 118 & 1.3 & 1.3 & 100 & 1.3 & 1.3 & 10 \\
\hline - over $50 \mathrm{~kW}$ & 2.2 & 6.2 & 282 & 2.0 & 5.8 & 290 & 1.3 & 4.2 & 323 & 1.2 & 3.1 & 258 \\
\hline Tractor trailers & 10.8 & 9.2 & 85 & 7.9 & 10.4 & 132 & 4.1 & 4.8 & 117 & 4.5 & 4.3 & 96 \\
\hline Reloading equipment & 2.1 & 3.9 & 186 & 4.3 & 6.4 & 149 & 1.6 & 3.0 & 188 & 1.0 & 1.9 & 190 \\
\hline $\begin{array}{l}\text { Machines and equipment: } \\
\text { - tillers }\end{array}$ & 39.6 & 43.1 & 109 & 29.7 & 36.1 & 122 & 12.3 & 15.6 & 127 & $.7 \mid$ & .8 & \\
\hline - ridgers & 7.6 & 6.3 & 83 & 6.0 & 5.5 & 92 & 1.0 & 0.9 & 90 & 0.4 & 0.4 & 100 \\
\hline - fertilizer and lime distributors & 7.4 & 8.1 & 109 & 6.0 & 7.5 & 125 & 3.7 & 3.9 & 105 & 0.6 & 0.9 & 150 \\
\hline - seed drills & 7.7 & 7.5 & 97 & 6.7 & 6.9 & 103 & 2.8 & 3.7 & 132 & 0.4 & 1.2 & 300 \\
\hline - sprayers & 6.2 & 10.3 & 166 & 7.1 & 7.8 & 110 & 2.8 & 3.7 & 132 & 0.7 & 1.7 & 243 \\
\hline Combine harvesters & 2.3 & 1.8 & 78 & 2.9 & 2.5 & 86 & 1.0 & 1.1 & 110 & 0.9 & 0.7 & 78 \\
\hline Balers & 2.0 & 1.8 & 90 & 6.0 & 6.5 & 108 & 2.0 & 3.3 & 165 & 1.0 & 1.2 & 120 \\
\hline Root cr & 1.2 & 1.2 & 100 & 2.3 & 2.0 & 87 & 0.5 & 0.4 & 80 & 0.2 & 0.2 & 100 \\
\hline Curra & 0.7 & 1.1 & 157 & 0.3 & 0.3 & 100 & 0.0 & 0.0 & 0 & 0.3 & 0.6 & 200 \\
\hline Feed making machines & 2.0 & 2.5 & 125 & 1.5 & 2.6 & 173 & 0.6 & 0.5 & 83 & 2.1 & 2.3 & 110 \\
\hline
\end{tabular}

by - base year (before subsidies), ty - target year (after subsidies)

Table 3. Equipment of farms with tractors and major agricultural machinery with respect to holding income

\begin{tabular}{|c|c|c|c|c|c|c|c|c|c|c|c|c|}
\hline \multirow[b]{3}{*}{ Specification } & \multicolumn{12}{|c|}{$\begin{array}{l}\left.\text { Agricultural equipment (pcs } \cdot 100 \mathrm{ha}^{-1} \mathrm{AL}\right) \text { in holdings with respect to income } \\
\left(\mathrm{K} \mathrm{PLN} \cdot \text { holdings }^{-1}\right)\end{array}$} \\
\hline & \multicolumn{3}{|c|}{$<10$} & \multicolumn{3}{|c|}{$10-20$} & \multicolumn{3}{|c|}{$20-50$} & \multicolumn{3}{|c|}{$>50$} \\
\hline & by & ty & $\begin{array}{c}\text { change, } \\
\text { base } \\
\text { year }= \\
100\end{array}$ & by & ty & $\begin{array}{c}\text { change, } \\
\text { base } \\
\text { year }= \\
100\end{array}$ & by & ty & $\begin{array}{c}\text { change, } \\
\text { base } \\
\text { year }= \\
100\end{array}$ & by & ty & $\begin{array}{c}\text { change, } \\
\text { base } \\
\text { year }= \\
100\end{array}$ \\
\hline Total tractors, including: & 14.4 & 22.0 & 153 & 10.1 & 13.7 & 136 & 7.1 & 9.5 & 134 & 2.9 & 4.8 & 166 \\
\hline- up to $30 \mathrm{~kW}$ & 6.9 & 8.1 & 117 & 3.5 & 3.5 & 100 & 2.0 & 1.9 & 95 & 0.4 & 0.3 & 75 \\
\hline$-30-50 \mathrm{~kW}$ & 5.7 & 9.5 & 167 & 4.1 & 5.1 & 124 & 3.3 & 3.9 & 118 & 1.1 & 1.1 & 100 \\
\hline - over $50 \mathrm{~kW}$ & 1.8 & 5.5 & 306 & 2.5 & 5.9 & 236 & 1.8 & 3.8 & 211 & 1.5 & 4.9 & 327 \\
\hline Tractor trailers & 8.5 & 9.3 & 109 & 10.7 & 12.3 & 115 & 5.9 & 6.7 & 114 & 4.0 & 4.7 & 118 \\
\hline Reloading equipment & 4.3 & 5.8 & 135 & 3.4 & 5.6 & 165 & 0.6 & 3.3 & 550 & 2.4 & 3.7 & 154 \\
\hline $\begin{array}{l}\text { Machines and equipment: } \\
\text { - tillers }\end{array}$ & 46.6 & 53.5 & 115 & 28.5 & 36.5 & 128 & 19.1 & 22.9 & 120 & 12.1 & 11.4 & 94 \\
\hline - ridgers & 10.8 & 10.4 & 96 & $\begin{array}{r}20.1 \\
5.1\end{array}$ & 4.4 & 86 & 0.8 & 0.8 & 100 & $\begin{array}{r}1.7 \\
1.7\end{array}$ & 0.8 & 47 \\
\hline - fertilizer and lime distributors & 8.7 & 10.1 & 116 & 6.6 & 7.4 & 112 & 3.6 & 5.0 & 139 & 2.8 & 3.1 & 111 \\
\hline - seed drills & 8.4 & 9.1 & 108 & 6.9 & 7.7 & 112 & 3.2 & 3.7 & 116 & 3.4 & 3.0 & 88 \\
\hline - sprayers & 10 & 13.8 & 138 & 5.5 & 7.2 & 131 & 3.8 & 5.4 & 142 & 2.2 & 2.2 & 100 \\
\hline Combine harvesters & 2.2 & 1.6 & 73 & 2.3 & 2.3 & 100 & 2.1 & 2.1 & 100 & 1.1 & 1.0 & 91 \\
\hline Balers & 5.3 & 4.4 & 83 & 5.0 & 6.0 & 120 & 2.8 & 4.9 & 175 & 1.6 & 2.1 & 131 \\
\hline Root crop harvesters & 2.3 & 1.9 & 83 & 2.2 & 2.2 & 100 & 0.4 & 0.4 & 100 & 0.6 & 0.5 & 83 \\
\hline Currant harvesters & 0.5 & 0.5 & 100 & 0.0 & 0.0 & 0 & 1.2 & 1.8 & 150 & 0.1 & 0.1 & 100 \\
\hline Feed making machines & 1.6 & 2.9 & 181 & 1.4 & 2.6 & 186 & 0.6 & 0.9 & 150 & 0.8 & 1.0 & 125 \\
\hline
\end{tabular}

by - base year (before subsidies), ty - target year (after subsidies) 


\section{SUMMARY}

The level of mechanization of holdings with respect to the amount of subsidy, their economic size and income in the period before and after receiving subsidies, shows a growing tendency. The highest level is in the groups, respectively: from 100 to 150 thousand PLN'holdings ${ }^{-1}$, over 40 ESUs and from 20 to 50 thousand PLN'holdings ${ }^{-1}$. Holdings of smaller sizes, which at the same time received lower subsidies (up to 50 thousand PLN), in comparison with the ones with subsidies over 150 thousand PLN have a higher level of mechanization - tractors and tillers: 50.0 and 47.1 and 121.4 and 84.3 pcs 100 holdings $^{-1}$. The greatest changes in the level of mechanization of holdings in the target year with in comparison with the base year was noted in the group of holdings with the amount of subsidies between 100 and 150 thousand PLN (number of tractors with a power over $50 \mathrm{~kW}$ - an increase by $450 \% \mathrm{pcs} \cdot 100$ holdings $^{-1}$ ). In all the studied groups the highest increase (ca. 200\%) was noted in the number of tractors with a power over $50 \mathrm{~kW}$, which can indicate the use of more efficient tools and machinery. In groups of holdings with the highest value of the division criteria, the efficiency of support machinery is considerably higher than in groups with smaller values of the division criteria. For example, in holdings with the amount of subsidy up to 50 and over 150 thousand PLN and with economic size of up to 8 ESUs and over 40 ESUs, the change in the percentage of spraying machines was, respectively: 31 and $66 \%$ and 60 and $143 \%$.

A multidirectional analysis of these holdings confirms that an increase in the economic size (ESU) and in the amount of subsidies has a considerable influence on the level of mechanization of holdings. The evaluation of the relationship between received funds and the technical modernization of the holdings under study, in the context of sustainable development, allows us to conclude that social sustainability is present in small holdings. It increases the comfort and quality of work and reduces the number of, for example, drives of combined cultivators in fields. Support programs for agriculture from EU funds are an important and effective factor in the shaping of technical modernization of family holdings.

\section{REFERENCES}

Kocira S., Sawa J. (2008). Techniczne uzbrojenie procesu pracy w różnych typach gospodarstw rolniczych. Inżynieria Rolnicza. No. 2 (100). pp. 83-87.

Muzalewski A. (2007). Ekspertyza „Modernizacja gospodarstw rolnych” w ramach PROW 2007-2013. IBMER, Warszawa.

Muzalewski A. (2008). Zasady doboru maszyn rolniczych. IBMER, Warszawa.

Plan rozwoju obszarów wiejskich na lata 2004-2006. (2004). MRiRW.

Program rozwoju obszarów wiejskich na lata 2007-2013. (2007). MRiRW.

Sawa J. (1994). Niektóre aspekty racjonalnego inwestowania w maszyny rolnicze. Materiały konferencyjne AR - Racjonalna mechanizacja gospodarstw rodzinnych. Lublin. pp. 108-116.

Sawa J. (2008). Próba oceny zrównoważenia procesów produkcji rolniczej. Inż. Roln. 2 (100), 257-262.

Sawa J., Huyghebaert B., Burny P. (2006). Nakłady energetyczno-materiałowe w aspekcie

zrównoważonej produkcji rolniczej. Inż. Roln. 13 (88), 417-422.

Sektorowy Program Operacyjny „Restrukturyzacja i modernizacja sektora żywnościowego oraz rozwój obszarów wiejskich". (2004). MRiRW.

Strategia rozwoju powiatu biłgorajskiego na lata 2007-2015. (2008). Zarząd powiatu w Biłgoraju, pp. 59-74.

Tabor S. (2004). Kierunek gospodarowania a wyposażenie techniczne i koszty mechanizacji produkcji rolniczej. Inż. Roln. II, 4 (59), pp. 225-232.

Wasąg Z. (2008). Level of adaptation of family agricultural holdings to EU standards, in: Farm machinery and process management in sustainable agriculture. III International Scientific Symposium, Gembloux, Belgium. Wallon Agicultural Research Centre (CRA-W), T. 2, pp. 88-92.

Wójcicki Z., Pawlak J. (1996). Stan i kierunki rozwoju techniki rolniczej w Polsce. IBMER, Warszawa. 